\title{
HISTORICAL-MEMORIAL EXPEDITION OF 1909 TO THE COSSACK TERRITORIES OF THE LOWER STREAM OF THE DNIEPER, MADE BY MEMBERS OF THE ODESSA BRANCH OF THE RUSSIAN MILITARY HISTORICAL SOCIETY
}

\section{Olexsandr Muzychko}

$\mathrm{PhD}$ (History), Associate Professor

Odessa I. I. Mechnikov National University

2, Dvoryanska Str., Odessa, 65082, Ukraine

sandro06@ukr.net

On the territory of the steppe part of the Southern Ukraine, the attention of scientists and the public attracted and attracted the places where the activities of the Ukrainian Cossacks unfolded, its cradle - Zaporozhchina, Sicheslavshchina. At the end of the nineteenth and early twentieth centuries. first of all thanks to the efforts of the Titans of historiographical, ethnographic, literary and mytho-poetic ideological creativity Y. P. Novitsky, A. F. Kashchenko, D. I. Yavornytsky, this place seemed to be "debunked", which made it a new, attractive, color for many of their contemporaries, and acquired the signs of sacredness that remains to this day, despite the catastrophic consequences of flooding with man-made reservoirs. Today, there are projects of physical revival, liberation from the watercourses, these territories, which, of course, will rebuild not only archaeological and scientifichistorical research, but also the symbolic-memorial movement with renewed vigor.

The purpose of this article is to highlight one of the brightest moments in the process of involving Cossack places in the memorial space - excursions there the members of the Odesa branch of the Imperial Russian Military Historical Society, which took place in May 1909. The appeal to this episode is due to the fact that it covers a few important aspects: the little-known activity of the military society and the part of the biography of "Cossack father" D. I. Yavornytsky. Thus, a trip to the members of the Odessa Military Society in the Cossack places of the Dnieper under the leadership of D.I. Yavornytsky strengthened cooperation between the Odesa and Katerynoslav centers of historical science, which was clearly reflected during the Katerynoslav archaeological congress in 1905. In a more global sense, the journey is one of the important episodes of the complex interaction process of various factors in shaping the historical memory of Ukrainian history, the Cossacks. Members of the Odesa Military Society were sympathizers of imperial patriotism, however, their journey and subsequent activity on perpetuating the memory of the Cossacks was advantageous for the Ukrainian model of nationbuilding. This process was skillfully moderated by such a charismatic leader as D. I. Yavornytsky Thus, we see an illustration of the importance of the personal factor in history, the great role of romantic representations in historical research.

Key words: expedition, Odesa branch of the Russian military-historical society, officers, military-historical researches, studying of the Cossacks. 


\section{ІСТОРИКО-МЕМОРІАИЬНА ЕКСПЕДИЦІЯ 1909 р. ПО КОЗАЦЫКИХ МІСЦИНАХ НИЖНЬОЇ ТЕЧІЇ ДНІПРА ЧАЕНІВ ОДЕСЬКОГО ВІДДІАЕННЯ РОСІЙСЬКОГО ВІЙСЬКОВО-ІСТОРИЧНОГО ТОВАРИСТВА}

Метою иієї статті є висвітлення одного з яскравих моментів у проиесі залучення козацьких місиин у меморіальний простір - екскурсї членів Одесъкого відділу Імператорсъкого Російсъкого війсъково-історичного товариства, яка відбулася у травні 1909 р. Зроблено висновок, шо подорож одеситів по козаиьких місиевостях Дніпра під керівниитвом Д.І. Яворнииького зміинила співпраию між одеським та катеринославським иентрами історичної науки, була одним з важливих епізодів проиесу складної взаємодії різних чинників у формуванні історичної пам'яті про украӥнсъку історію, козаитво.

Ключові слова: експедииія, Одесъке відділення Російсъкого війсъково-історичного товариства, офрічери, війсъково-історичні дослідження, козакознавство.

Початок XXI ст. позначений бурхливим розвитком туристичної галуззі. Неодмінним компонентом туризму є історичне пізнання, що спирається на здобутки історичної науки та краєзнавства. Попри економічні негаразди, бачимо дедалі більшу кількість випадків відродження, переосмислення, ребрендінгу, надання туристичної привабливості, щодо історико-меморіальних об’єктів у різних частинах України. Велике значення "одухотворення", візуалізації, історії було цілком очевидним у XIX - на початку XX ст. 3 цим пов'язаний музейницький, пам'яткооохоронний рухи. Влада Російської імперії, у межах якої перебувала більша частина тогочасної України, намагалася використати природнє прагнення інтелігенції до збереження історичної спадщини у цілях втілення імперської моделі історичної пам'яті і відповідного історико-патріотичного виховання.

В свою чергу, національна інтелігенція прагнула використати інтенції вцади у вцасних інтересах, надання певним об'єктам свого, національнопатріотичного звучання. Закономірно, що екскурсії дедалі більше поширювалися як один 3 дієвих методів пізнання історії та географії у навчальному процесі [6, с. 149-154]. Екскурсії по історичних місцях були важливим компонентом роботи виставок, археологічних з`іздів, які кожні три роки проводилися у різних містах Російської імперії, зокрема, й в Україні. Ці акції об’єднували аматорів історії та фрахівців.

На території степової частини Південної України закономірно велику увагу науковців та громадськості привертали та привертають місцини, на яких розгорталася діяльність українського козацтва, його колиска Запорожчина, Січеславщина. Наприкінці XIX - на початку XX ст. передусім завдяки зусимлям титанів історіографічної, етнографічної, мітературної та міфо-поетичної ідеологічної творчості Я. П. Новицького, А. Ф. Кащенка, Д. І. Яворницького цю місцину наче вдалося "розговорити", завдяки чому вона заграла новими, привабливими, фарбами для багатьох їх сучасників, набула ознак сакральності, що зберігається до сьогодні, незважаючи на 
катастрофічні наслідки від затоплення рукотворними водосховищами. Сьогодні існують проекти фізичного відродження, звільнення від водних обширів, цих територій, що, безумовно, 3 новою симою відродить не мише археологічні та науково-історичні дослідження, але й символічномеморіальний рух.

Метою цієї статті є висвітлення одного з яскравих моментів у процесі залучення козацьких місцин у меморіальний простір - екскурсії членів Одеського віддіку Імператорського Російського військово-історичного товариства (далі-ОВIPВIT), котра відбулася у травні 1909 року. Звернення до цього епізоду зумовлено тим, що він охоплює кілька важливих аспектів: маловивчену діяльність ОВIPВIT та $є$ частиною біографії "козацького батька" Д. І. Яворницького. Ця подія маконічно описана в одній статті, дніпровського історика та "кіборга", героя російсько-української війни, К. М. Недрі та просто згадана у кількох інших [7, с. 58; 8, с. 173-179]. Але він не використав надзвичайно цінне та унікальне щодо цієї події джерело: докладний опис екскурсії, що навів один 3 іiі головних ініціаторів та втілювачів П.М. Андріанов. Цей опис $є$ всі підстави вважати одним 3 цінних спогадів про Д. І. Яворницького, хоча він був написаний по зовсім гарячих слідах, через місяць після події. Припустимо, що йдеться про взагалі перший текст, який можна вважати спогадом про козакознавця, адже більшість перших подібних текстів про нього з'явилися з нагоди 30-ччя його діяльності у 1913 р. Проте, це джерело залишилося невідомим (а відтак i не залученим) для краєзнавця М. П. Чабана, упорядника збірника спогадів про Д.І. Яворницького. Не згадано про цю публікацію ані у бібліографіях творів про Д. І. Яворницького, ані у його новітніх біографіях.

На початку XX ст. Одеса належала до потужних культурних осередків Російської імперії. Одним з відображень цього факту було функціонування у місті цілої низки суто наукових та просвітницько-гуманітарних товариств. Частина 3 них вели початок з XIX ст., наприклад, знане далеко за межами Одеси Одеське товариство історії та старожитностей (ОТІС). Значна кількість товариств виникла після мібералізації процесу створення громадських об'єднань у 1905 р. Одеський професор I. А. Аинниченко у 1911 р. іронічно зауважував, що "нові товариства виростають в нас останнім часом зі швидкістю, що здатна викликати заздрість в різних садівників" [5, с. 1]. Серед них на особливу увагу заслуговує ОВIPBIT, адже об'єднання військових задля дослідження військової історії було новим історіо-графічним явищем. Імператорське Російське військово-історичне товариство було засновано у 1907 р. у Санкт-Петербурзі, а його одеське віддімення - у мистопаді 1908 р., другим після Московського.

Відкриття відділення в Одесі було зумовлено значним потенціалом, що на той момент накопичився тут у галузі військово-історичних досліджень, наявності низки військових навчальних закладів, де викладали зокрема й військову історію, низки ентузіастів справи, декількох періодичних військових видань, книгарні військової книги і т.п. Ідеологічним приводом для активізації історико-військових досліджень було підсилення патріотичного виховання в умовах "зализування ран" після поразки у російсько-японській війні, підготовки до бучного відзначення перемоги Петра I у Полтавській баталії, заплановане у 1909 р.

Поряд 3 мекційною (фактично пропагандивною), дослідницько-популяризаторською роботою центральне товариство та його філії активно вкАючилося у процес польового вивчення старожитностей, пов'язаних 3 
військовою історією, що мало сприяти розвитку іншої вагомої складової в його діяльності - пам'яткоохоронної. Про необхідність охорони військових пам'яток, головним чином військових цвинтарів, наголосив у своїй доповіді 9 травня 1909 р. один з провідних членів одеського відділення полковник M. I. Кіяновський. Польові дослідження пам'яток, у формі так званих "екскурсій" (у даному разі це туристичне слово не точно відображає мотивацію та завдання, яке ставими перед собою їх організатори і тому більше пасує слово експедиція) практикувалися ОТІС та планувалися іншими товариствами, хоча частіше без особливого успіху з огляду на організаційні труднощі. У військових були очевидні переваги з огляду на специфіку їх підготовки та діяльності. Недаремно юнкера Одеського кадетського корпусу здійснювали на початку XX ст. подорожі під час яких отримували яскраві уявлення про географію та стан історичних пам'яток. Великим поштовхом для розгортання діяльності ОВІРВІТ була велика особиста зацікавленість командуючого військами Одеської військової округи генерала, барона О. В. Каульбарса. Маючи великий досвід польових географічних досліджень, генерал мав усі підстави спонукати до аналогічної діяльності членів товариства. Більшість одеських товариств прагнули не замикатися у своїй польовій діяльності мише на Одесі.

Закономірно, що одним з об’єктів уваги OBIPBIT були обрані місцини Наддніпрянщини, пов'язані 3 козацьким минулим, добре відомі в Одесі зацікавленим особам завдяки дослідженням та публікаціям А. О. Скальковського, Ф. К. Бруна, Я. П. Новицького та Д. І. Яворницького. В ідеологічній структурі Російської імперії козакам була відведена роль в рамках

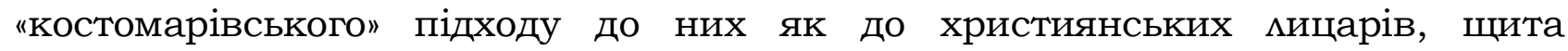
православ'я, що цілком узгоджувався з концепціями патріотичної пропаганди. Додатковим стимулом до зацікавлення козацькими звитягами було регулярне перебування в Одесі корпусів донського козацтва, проживання та навчання у цьому місті представників козацького стану, або вихідців з нього. У 1904 р. Одеська міська дума перейменувала вулицю Глуху на Молдаванці на вулицю Запорізьку [3, с. 183]. На початку XX ст. козацькі місцини стають центром "паломництва" громадськості, зокрема, учнівської молоді. Так, район Ненаситецького порогу відвідували разом з вчителями учні Ананївської, Херсонської, Александрійської шкіл. Велику роботу 3 популяризації українського козацтва вела одеська "Просвіта" у 1906 - 1909 роках.

Особливе, націєтворче, значення мав цей район для адептів українського національного світогляду та руху. Ясна річ, головну роль у налагодженні відвідування цих районів відігравали катеринославські українці: Д. І. Яворницький, Я. П. Новицький, А. В. Синявський, Д. Сигаревич. Про одну з таких поїздок яскраво згадав Д. І. Дорошенко [2, с. 122-123]. Щоправда, він же відобразив головну проблему під час цих подорожей - складність пробудження в не-українських ментально та культурно учнів тих романтичних українських національних почуттів, які поділяли i на які очікували від оточення українські націєтворці. Вочевидь, ця проблема виникала не раз і в інших українців під час подорожей. Щоправда, бували i зворотні випадки, про що свідчать спогади польського катеринославського гімназиста Єжи Єнджеєвича. Краєвиди козацьких місцин збуджували його уяву, викликали історичні образи, підсилюючись прочитаними творами Г. Сєнкевича та Д. I. Яворницького, 3 яким він мав можливість й спілкуватися [15, с. 68-70]. Про великі успіхи Д. І. Яворницького у справі "втягування" не-українців в історичну романтику українського степу свідчать 
спогади гімназиста Г. І. Канцельсона, опубліковані у 1905 р. у петербурзькому виданні [15, с. 32-41]. На 1909 р. катеринославський історик вже мав славу головного спеціаліста та талановитого популяризатора, зокрема, провідника, по козацькій минувшині. Двома органічними частинами козацького простору, що поєднувався вченим, був Катеринославський музей імені О. М. Поля та козацькі місцини біля Дніпра.

Одним з вагомих компонентів кола спілкування Д. І. Яворницького були військові. Дия них він був джерелом історичних уявлень про військові звитяги їх предків, а вони для нього - порадниками та помічниками, а іноді й меценатами його діяльності. Д. І. Яворницький був дійсним членом Імператорського Російського Військово-історичного товариства, факт про який не часто згадується у мітературі про нього. Саме Д. І. Яворницький дав безпосередній поштовх членам OBIPBIT, адже він прочитав на одному з його засідань доповідь "Про бойове минуме Запорізького війська".

Рішення ОВIРВIT про «військово-історичної поїздки для огляду військових пам'ятників на нижній течії Дніпра" було прийнято на одному 3 його засідань 13 квітня 1909 р. Оголошення у одеській пресі про проведення поїздки від 14 до 18 травня з'явимося 6 травня [13]. Організатори повідомляли, що збірним пунктом призначено Катеринославський музей ім. О. М. Поля та просили надсилати письмові заявки секретарю ОВIPВIT. Витрати на проведення мали брати на себе учасники. Про свої плани провести порогами Дніпра «православне воїнство» повідомляв Д.І. Яворницький у мисті до $Є$. Х. Чикаленка та запрошував його взяти участь.

Газети висвітлювали хід експедиції. Так, "Русская Речь» повідомляла 3 Олександрівська 17 травня, що екскурсія спустилася із Катеринослава через пороги по Дніпру та прибула до Олександрівська. 29 травня на засіданні OBIPBIT його секретар П. М. Андріанов доповів про поїздку, що тривала 314 по 18 (в інших джерелах - по 19) травня. Ще майже через місяць в одній 3 найбільших одеських газет [9] та у головній військовій столичній газеті Російської імперії "Русский инвалид" [14] П. М. Андріанов опублікував вище згаданий великий звіт про подорож, що є на сьогодні головним джерелом для реконструкції перебігу цієї непересічної події, першої в історії ОВIPВIТ. Ця стаття незрівнянно повніше надає інформацію про подорож, аніж сухий звіт, що був опублікований у звіті центрального Військово-історичного товариства $[11$, с. 40-41]. Восени 1909 p. О. В. Каульбарс доповів про подорож імператору під час особистої аудієнції та висунув низку ініціатив, що були схвально ним сприйняті.

Стаття П. М. Андріанова компенсує дуже стисле повідомлення про цю подорож, що з'явилася на сторінках 6-го випуску " $\Lambda$ топису" Катеринославської вченої архівної комісії [4, с. 241]. До того такі подорожі були справою окремих ентузіастів та педагогічних колективів та учнів. Хоча найпомітнішим та найіменитішим учасником подорожі був голова OBIPBIT генерал О. В. Каульбарс, що, власне, і був "ключем", що відкривав усі потрібні для організації двері, безсумнівно, головним мотором цієї акції був підполковник, викладач Одеського військового учимища, Павцо Маркович Андріанов (1877 - 1918) - душа OBIPBIT і найпомітніший військовий історик Одеси перших десятиліть ХX ст., відомий далеко поза межами Одеси. У столиці він неодноразово отримував премії та винагороди за свою діяльність. Сучасні українські, в тому числі, одеські, історики вважають за доцільне посиматися на його праці, зокрема, черпаючи 3 них барвисті характеристики військових операцій [1, с. 12]. В контексті сучасного 
ювілейного року варто наголосити, що П. М. Андріанов загинув, захищаючи Гетьманат П. Скоропадського [10].

На початку свого повідомлення про подорож П. М. Андріанов навів історичний екскурс значення Дніпра в історії Русі, що свідчить про те, що він цілком поділяв неоромантичний погляд на історію Д. І. Яворницького, який, без сумніву, був дия нього одним з джерел натхнення та історичних знань. Окремий абзац П. М. Андріанов присвятив глорифікації Запорізької Січі "авангарду Руської землі", захисника пригніченої України. Аише з цієї статті ми дізнаємося, що кількість учасників експедиції становима 26 осіб. На жаль, персонально згадано окрім Д. I Яворницького, П. М. Андріанова, О. В. Каульбарса, мише генерал-лейтенанта Дмитра Микомайовича Безрадецького. Подорож розпочалася з трьохгодинної екскурсії по музею імені О. М. Поля, яку провів Д. І. Яворницький. Після того учасники оглянули Потьомкінський палац, пам'ятник Катерині II. П. М. Андріанов дорікнув містянам за захаращеність цього пам'ятника. Дия нас же це $є$ свідченням того, що культ імператриці не мав щирого народного поширення, підтримувався штучно, при чому навіть без особливого захоплення навіть з боку владних чинників.

Від пристані Катеринославського яхт-клубу на пароплаві 3 якоюсь футуристичною назвою "Робітник" екскурсанти піднялися вгору притокою Дніпра Самарою до руїн Новобогородицької фрортеці, що була споруджена князем В. В. Голіциним під час його невдалої інвазії у Крим. Оглянувши руїни, екскурсанти поплили на південь по Дніпру до порогів. Переночували вони у маєтку "Чапля" графра Воронцова-Дашкова, неподалік від Кайдацького порогу. Перед сном вони прослухали мекцію з історії краю Д.І. Яворницького. На наступний день подорож продовжилася на двох "дубах" під керівництвом знаменитих дніпровських моцманів. Пройшовши Кайдацький поріг, учасники екскурсії пристали до правого берегу біля села Старий Кодак, де оглянули споруджену Г. Бопланом фортецю. В місцевих мешканців були отримані декілька старих ядер та куль тощо. Ці предмети було заплановано передати у майбутній Військово-історичний музей OBIPBIT (у повноцінну установу цей музей так і не розвинувся).

Потім експедиція підійшла до Ненаситецького порогу. 17 травня настав кульмінаційний момент подорожі - спуск на чотирьох "дубах" по Ненаситецькому порогу, яскраво описаний П. М. Андріановим: "Молись Богу!» - наказали моцмани. Знявши капелюхи, веслярі побожно хрестяться та шепочуть молитву. Для розгону дуби вигрібають спочатку версти на $1 \frac{1}{2}$ вище порогу, потім поворот та дуб, керований досвідченою рукою моцмана, 3 швидко зростаючою швидкістю спрямовується до каналу. Ви цілком у владі швидко несучого потоку. Дуб мчить зі швидкістю потягу, безшумно ковзаючи по водній поверхні, що піниться. Майже з поверхні ріки ви бачите профіль водоспаду. Хвимя, розбиваючись на найменші бризки, обдає дуб та його пасажирів. Симьне хвимювання сильно розгойдує дуб. Особливо бурлить вода біля виходу із каналу, перед тим, як вирватися на простір. У кожному дубі $\epsilon$ постраждалі: сицьно политі Дніпровською водою - це "запорізьке хрещення", заспокоює Д. І. Яворницький". Пройшовши кілька дрібних порогів, екскурсанти зробими привал на острові Перун. Поблизу Кічкасу учасники пересіли з дубів на пароплав з символічною назвою "Україна", що приплив 3 Олександрівська. Поблизу Кічкасу екскурсанти пройшли крізь "Вовче горло" найвужче місце на Нижньому Дніпрі, відвідали острів Велика Хортиця та приплики в Олександрівськ. 
Екстреним потягом учасників доставили 3 Олександрівська у місто Нікополь, на конях доїхали до села Копиловка, а звідти знову на дубах - на місце Чортомлицької Січі. Тут за пропозицією О. В. Каульбарса було встановлено дерев'яний хрест, проведено пробні розкопки. П.М. Андріанов згадував, що приїзд гостей викликав великий ажіотаж в населення, що натовпом стікалося подивитися на них. Прибув священик, який проголосив вічну пам'ять запорізькому козацтву, відбулася велелюдна молитва. Екскурсанти прийняли рішення встановити тут у подальшому кам'яний запорізький хрест. Від Чортомлику екскурсанти поїхали на місце останньої, Підпільненської, Січі. Власне, тут історична частина подорожі і завершилася (К. М. Недря помилково називає кінцевим пунктом подорожі м. Нікополь). Надалі учасники відправилися у село Грушівку, до маєтку великого князя Михайла Миколайовича, де під час дружньої бесіди обговорили чотириденну мандрівку. На станції Долгищево, звідки у різні напрямки розіхалися екскурсанти, вони відправили телеграми імператору та очільника центрального військово-історичного товариства. Текст статті П. М. Андріанова пересипаний проникливими позитивними характеристиками керівника подорожі Д. І. Явор-ницького та його дітища - катеринославського музею, котрий, за його словами "усім нам став близькою, дорогою,

"Вже далеко позаду залишився Дніпро, його бурхииві пороги, його живописні берега, але яскраве враження пережитих днів поїздки було ще свіжим та повним очарування. Згадувалися в усіх подробицях оповідання Д. І. Яворницького про минулі подвиги славних запорожців, про оригінальний побут січовиків, також згадувалися розказані ним мегенди, цікаві казки про відьом, чортах, постійно страждаючих від різних підступів запорожців. Жива мова Дмитра Івановича, приправлена чистим українським [принагідно наголосимо, що скрізь по тексту П. М. Андріанов використав саме таке визначення - український, а не "махоросійський" - O. M.] гумором, надовго збережеться у пам'яті учасників подорожі», - згадував одеський автор.

Свою статтю П.М. Андріанов завершив апологією таких історичних екскурсій, що, на його переконання, «сприяють живому безпосередньому пізнанню нашої Батьківщини, зародженню гарячою бойового минулого руського народу. Замість книжної історичної науки, ви осягаєте минуле на конкретних предметах. Низка симьних вражень під час оглядин історичних місць, що ми послідовно пережили, залишить у нашому розумі та серці незнищенний слід на все життя. Ви не захопцені усім побаченим, але у вас появиться сильна необхідність поділитися винесеними враженнями з іншими, зі всім вашим оточенням, а при тому, безумовно, проявлений буде той самий моральний вплив, що у нашій військовій справі зароджує високу духовну засаду, що має виключно важливе значення".

Ці тези підтверджує той фракт, що подорож членів ОВIPВIT по Дніпру справді мала корисні наслідки. Найбільш яскраве втілення отриманий заряд вражень від наочного ознайомлення з козацькою минувшиною втілився у піднесено-апологетичній статті П. М. Андріанова про запорізьке козацтво 3 яскравою назвою "Славное низовое Запорожское войско", що була з деякими варіаціями опублікована окремою брошурою в Одесі та в одному з одеських видань та у столичному головному військовому періодичному виданні Російської імперії "Военном журнале». Під явним впливом Д. І. Яворницького одеський історик у російськомовному тексті використав український варіант написання слова "Січ", який прийняла редакція, оговоривши це у спеціальній 
примітці. У межах російського історичного світогляду, що фактично виправдовував міквідацію Запорізької Січі, автор, проте, наситив текст багатьма яскравими характеристиками "мицарів степу", що залишали безумовно позитивне враження про них, що могло прислужитися і завданням українського націєтворення. Праця нагадувала, наприклад, текст М. М. Аркаса і цілком могла використовуватися у відповідній просвітницькій роботі.

OBIPBIT висунуло низку ініціатив, спрямованих на охорону пам'яток минулого та увічнення українського козацтва. Вперше про ці ініціативи заявив у клопотанні до катеринославського земства О. В. Каульбарс, котре виголосив Д. І. Яворницький 14 грудня 1909 р. на губернському земському зібранні, в якому було згадано і про подорож. Йшлося про реставрацію катеринославського пам'ятника Катерині II, встановлення пам'ятної стели на місці Кодацької фортеці, виготовлення та встановлення меморіальної плити на Ненаситецькому порозі. Ці ініціативи були схвалені і навіть частково фінансово підтримані. У роботу над пам'ятниками включився видатний скульптор Б. В. Едуардс. Чавунна дошка вагою приблизно 400 кг. була встановлена у 1913 р. на скелі Монастирко. ОВІРВІT домоглося перейменування у 1910 р. станції Катерининської залізниці з "Осокорівка" на "Чортомлик", перейменування Єйського полку Кубанського війська на Запорізький (з відзначення великої символічної ваги цього факту розпочав свою вище згадану статтю П. М. Андріанов). У 1910 р. чмен OBIPBIT полковник В. М. Кісляков прочитав у Катеринославі мекцію про Аейпцігську битву [12, с. 62].

Багато інших ініціатив (перейменування Нікополя на Микитин Ріг, встановлення пам'ятників у Нікополі Б. Хмельницькому та Микитинській Січі, меморіалу-каплиці на місці Чортомлицької Січі, надання двом полкам імен отамана Сірка та гетьмана Сагайдачного, облаштування могили I. Сірка) не були реалізовані. Нарешті, восени того ж 1909 р. ОВIPВIT здійснимо ще одну резонансну подорож, на цей раз по Дунаю. Значення дніпровської подорожі підвищується, якщо зважити на те, що навіть більш потужне за одеське, Київське віддімення Військово-історичного товариства, попри тривалі перемовини та зміни планів, так і не спромоглося організувати аналогічну екскурсію по Дніпру на чолі з Д. І. Яворницьким.

Таким чином, подорож членів ОВIРВIT по козацьких місцинах Дніпра під керівництвом Д.І. Яворницького зміцнила співпрацю між одеським та катеринославським центрами історичної науки, що яскраво відбилася вже під час проведення у 1905 р. катеринославського археологічного з'ізду. У більш глобальному плані, подорож $є$ одним з важливих епізодів процесу складної взаємодії різних чинників у формуванні історичної пам'яті про українську історію, козацтво. Чцени ОВІРВIT були прибічниками загальноімперського патріотизму, проте, об'єктивно їх подорож і подальша діяльність щодо увічнення пам'яті про козацтво була вигідна дия української моделі націєтворення. Цим процесом вміло модерував такий харизматичний мідер як Д. І. Яворницький. Таким чином, бачимо ілюстрацію важливості особистого чинника в історії, велику роль романтичних уявлень в історичних дослідженнях.

\section{Джерела та література:}

1. Гончарук Т.Г. Військові операції на території сучасної Одещини під час російсько-турецьких війн XVIII ст. Методичний посібник. Одеса, 2002. - 36 с. 2. Дорошенко Д. Мої спомини про давнє минуле (1901 - 1914). - Biнніпег, 1949. 
3. Журналы Одесской городской Думы. - 1904. - №3.

4. Аетопись Екатеринославской ученой архивной комиссии. - В. 6. - 1910.

5. Аинниченко И.А. Задачи библиографии: Речь, произнес. в собр. Одес. библиогр. о-ва при Новорос. ун-те 14 мая 1911 г. - Одесса : Центр. тип., 1911. - C. 1 .

6. Молочко Є. Вивчення, популяризація та охорона пам'яток історії та культури Севастополя : екскурсійна діяльність у другій половині XIX - на початку XX століття // Краєзнавство. - 2010. - № 1/2. - С. 149-154.

7. Недря К.М. Катеринославські проекти Одеського віддіяення Імператорського Російського воєнно-історичного товариства: плановані й реалізовані / К.М. Недря // Історія і культура Придніпров'я. Невідомі та маловідомі сторінки. - Вип. 10. - 2013. - С. 173-179.

8. Недря К. М. Інтелектуальний культурний простір Д. І. Яворницького / К. М. Недря // Історія і культура Придніпров'я. Невідомі та маловідомі сторінки. - 2014. - Вип. 11.

9. Одесский Аисток - 1909. - 23 июня. - № 142.

10. Одесский Аисток. - 1919. - 1 января. - № 479.

11. Отчет о деятельности Императорского Русского военно-исторического общества с 27-го августа 1907 г. по 1-е января 1909 г. - СПБ, 1909.

12. Отчет о деятельности Императорского Русского военно-исторического общества за 1910 год. - СПБ, 1911. - 95 с.

13. Русская Речь. - 1909. - 6 мая. - № 1018.

14. Русский инвалид. - 1909. - № 154, 155, 157.

15. Сучасники про Д. І. Яворницького / упор. Чабан М. - Д., 2006. - 238 с.

\section{References:}

1.Honcharuk T.H. Viys'kovi operatsiyi na terytoriyi suchasnoyi Odeshchyny pid chas rosiys'ko-turets'kykh viyn XVIII ct. Metodychnyy posibnyk. Odesa, 2002. - 36 s. [in Ukrainian].

2. Doroshenko D. Moyi spomyny pro davnye mynule (1901 - 1914). - Vinnipeh, 1949.

3. Zhurnaly Odesskoy horodskoy Dumy. - 1904. - №3. [in Canadian].

4. Letopis' Ekaterinoslavskoy uchenoy arkhivnoy komissii. - V. 6. - 1910.

5. Linnichenko I. A. Zadachi bibliografii: Rech', proiznes. v sobr. Odes. bibliogr. o-va pri Novoros. un-te 14 maya 1911 g. - Odessa : TSentr. tip., 1911.

6. Molochko Ye. Vyvchennya, populyaryzatsiya ta okhorona pam"yatok istoriyi ta kul'tury Sevastopolya : ekskursiyna diyal'nist' u druhiy polovyni XIX - na pochatku XX stolittya // Krayeznavstvo. - 2010. - № 1/2. - S. 149-154. [in Ukrainian].

7. Nedrya K. M. Katerynoslavs'ki proekty Odes'koho viddilennya Imperators'koho Rosiys'koho voyenno-istorychnoho tovarystva: planovani y realizovani / K. M. Nedrya // Istoriya i kul'tura Prydniprov'ya. Nevidomi ta malovidomi storinky. - Vyp. 10. 2013. - S. 173-179. [in Ukrainian].

8. Nedrya K. M. Intelektual'nyy kul'turnyy prostir D. I. Yavornyts'koho / K. M. Nedrya // Istoriya i kul'tura Prydniprov'ya. Nevidomi ta malovidomi storinky. - 2014. Vyp. 11. - S. 58. [in Ukrainian].

9. Odesskiy listok - 1909. - 23 iyunya. - № 142.

10. Odesskiy listok. - 1919. - 1 yanvarya. - № 479.

11. Otchet o deyatel'nosti Imperatorskogo Russkogo voyenno-istoricheskogo obshchestva s 27-go avgusta 1907 g. po 1-e yanvarya 1909 g. - SPB, 1909. S. 40-41. 
12. Otchet o deyatel'nosti Imperatorskogo Russkogo voyenno-istoricheskogo obshchestva za 1910 god. - SPB, 1911. - $95 \mathrm{~s}$.

13. Russkaya Rech'. - 1909. - 6 maya. - № 1018.

14. Russkiy invalid. - 1909. - № 154, 155, 157.

15. Suchasniki pro D. I. Yavornits'kogo / upor. CHaban M. - D., 2006. - 238 s.

\section{Историко-мемориальная экспедииия 1909 г. по казаиким местам Нижнего течения Днепра иленов Одесского отделения Российского военно-исторического обшества}

Целью этой статьи является освещение одного из ярких моментов в процессе оформления мемориального пространства - экскурсии членов Одесского отделения Императорского Русского военно-исторического общества, которая состоялась в мае 1909 года. Сделан вывод, что путешествие одесситов по казацким местностям Днепра под руководством Д. И. Яворницкого укрепима сотрудничество между одесским и екатеринославским центрами исторической науки, была одним из важных эпизодов сложного процесса взаимодействия разцичных факторов в формировании исторической памяти об украинской истории и казачестве.

ключевые слова: экспедиция, Одесское отделение Российского военноисто-рического общества, военно-исторические исследования, казаковедения.

Отримано 02.10.2018p. 